\title{
GAMBARAN DISTRESS PADA PENDERITA DIABETES MELLITUS
}

\author{
Deasti Nurmaguphita ${ }^{1}$ Sugiyanto $^{1}$ \\ ${ }^{1}$ Universitas 'Aisyiyah Yogyakarta \\ deastinurma@gmail.com
}

\begin{abstract}
ABSTRAK
Diabetes Mellitus (DM) merupakan salah satu penyakt kronis yang berpotensi mengalami komplikasi lebih berat seumur hidup pasien. Hal inilah yang menyebabkan banyak penderita DM mengalami distress. Distress yang dialami oleh pasien ini disebabkan oleh berbagai faktor penyebab dan berbagai respon pasien terhadap penyakitnya. Penelitian ini bertujuan untuk mengetahui bagaimana gambaran distress pada penderita DM. Penelitian dilakukan dengan metode deskriptif kuantitatif selama bulan Januari-Agustus 2018. Sampel sejumlah 44 penderita DM tipe II diambil secara accidental sampling di RS PKU Muhammadiyah Yogyakarta dan RS PKU Muhammadiyah Bantul. Instrumen penelitian menggunakan rekam medik dan kuesioner. Analisis hasil menggunakan program statistik komputer, dengan melihat distribusi frekuensi masing-masing domain. Hasil penelitian sebagian responden mengalami diabetes distress tingkat rendah $(50 \%), 45,5 \%$ responden mengalami diabetes distress tingkat sedang dan hanya sedikit $(4,5 \%)$ responden yang mengalami diabetes distress tingkat tinggi. Domain diabetes distress yang paling tinggi adalah distress beban emosional $(2,28)$, selanjutnya distress pengobatan $(2,14)$, distress dengan dokter/tenaga kesehatan $(2,09)$ dan nilai terendah terdapat pada distress interpersonal $(1,90)$. Saran perlu diberikan edukasi atau pelatihan yang dapat menguatkan respon emosional penderita DM tipe II misalnya konseling, terapi psikologis, keterampilan komunikasi dan peningkatan koping.
\end{abstract}

Kata kunci: Diabetes mellitus, distress, gambaran distress diabetes

\section{DISTRESS DESCRIPTION IN DIABETES MELLITUS PATIENTS}

\begin{abstract}
Diabetes Mellitus (DM) is a chronic disease that has the potential to experience more severe complications throughout the patient's lifetime. This is what causes many DM sufferers to experience distress. Distress experienced by these patients is caused by various causes and various patient responses to the disease. This study aims to determine how the picture of distress in DM patients. The study was conducted with quantitative descriptive method during January-August 2018. A sample of 44 patients with type II DM were taken by accidental sampling at PKU Muhammadiyah Hospital in Yogyakarta and PKU Muhammadiyah Hospital in Bantul. The research instrument used medical records and questionnaires. The results analysis uses a computer statistics program, by looking at the frequency distribution of each domain. The results of the study of some respondents experienced low level of diabetes distress (50\%), 45.5\% of respondents experienced moderate level of diabetes distress and only a few (4.5\%) of respondents experienced high levels of diabetes distress. The highest diabetes distress domain was emotional burden distress (2.28), then treatment distress (2.14), distress with doctors / health personnel (2.09) and the lowest score was interpersonal distress (1.90). Suggestions need to be given education or training that can strengthen the emotional response of patients with type II diabetes such as counseling, psychological therapy, communication skills and coping.
\end{abstract}

Keywords: Diabetes mellitus, distress, diabetic distress

\section{PENDAHULUAN}

Penyakit Tidak Menular (PTM) sudah menjadi masalah kesehatan masyarakat, baik secara global, regional, nasional dan lokal. Salah satu PTM yang menyita banyak perhatian adalah Diabetes Melitus (DM). Di Indonesia DM merupakan ancaman serius bagi pembangunan kesehatankarena dapat menimbulkan kebutaan, gagal ginjal, kaki diabetes (gangrene) sehingga harus diamputasi, penyakit jantung dan stroke. 
Global status report on NCD World Health Organization (WHO) tahun 2010 melaporkan bahwa $60 \%$ penyebab kematian semua umur di dunia adalah karena PTM. DM menduduki peringkat ke-6 sebagai penyebab kematian. Sekitar 1,3 juta orang meninggal akibat diabetes dan 4 persenmeninggal sebelum usia 70 tahun. Pada TAhun 2030 diperkirakan DM menempati urutan ke-7 penyebab kematian dunia. Sedangkan untuk di Indonesia diperkirakan pada tahun 2030 akan memiliki penyandang DM (diabetis mellitus) sebanyak 21,3 juta jiwa. International Diabetes Federation (IDF) menyatakan bahwa lebih dari 371 juta orang di dunia yang berumur 20-79 tahun memiliki diabetes. Sedangkan Indonesia merupakan negara urutan ke-7 dengan prevalensi diabetes tertinggi, di bawah China, India, USA, Brazil, Rusia dan Mexico (Kemenkes RI, 2017).

Dewasa ini ada sekitar 422 juta orang penyandang diabetes yang berusia 18 tahun di seluruh dunia atau $8,5 \%$ dari penduduk dunia. Namun 1 dari 2 orang dengan Diabetes tidak tahu bahwa dia penyandang Diabetes. Oleh karena itu, sering ditemukan penderita Diabetes pada tahap lanjut dengan komplikasi seperti; serangan jantung, stroke, infeksi kaki yang berat dan berisiko amputasi, serta gagal ginjal stadium akhir. $90 \%$ penderita diabetes di seluruh dunia merupakan diabetes tipe 2 yang disebabkan oleh gaya hidup yang kurang sehat.

Diabetes merupakan penyakit yang disebakan oleh tingginya kadar gula darah akibat gangguan pada pankreas dan insulin. Di Indonesia, data Riskesdas menunjukkan bahwa terjadi peningkatan prevalensi Diabetes di Indonesia dari 5,7\% tahun 2007 menjadi 6,9\% atau sekitar sekitar 9,1 juta pada tahun 2013. Data International Diabetes Federation tahun 2015 menyatakan jumlah estimasi penyandang Diabetes di Indonesia diperkirakan sebesar 10 juta. Seperti kondisi di dunia, Diabetes kini menjadi salah satu penyebab kematian terbesar di Indonesia. Data Sample Registration Survey tahun 2014 menunjukkan bahwa Diabetes merupakan penyebab kematian terbesar nomor 3 di Indonesia dengan persentase sebesar 6,7\%, setelah Stroke $(21,1 \%)$ dan penyakit Jantung Koroner (12,9\%). Bila tak ditanggulangi, Kondisi ini dapat menyebabkan penurunan produktivitas, disabilitias, dan kematian dini (Kemenkes, 2016)
Berdasarkan data World Economic Forum April 2015, potensi kerugian akibat Penyakit Tidak Menular di Indonesia pada periode 2012-2030 mencapai 4,47 triliun dolar, atau 5,1 kali PDB 2012. Besarnya pembiayaan kesehatan akibat Diabetes tampak dari klaim BPJS sampai tahun 2015. Ternyata Diabetes dan komplikasinya adalah salah satu kelompok klaim terbesar untuk biaya catastrophic JKN, yaitu $33 \%$ dari total pengeluaran. Itulah sebabnya, Agenda 2030 dari Sustainable Development Goals (SDGs) menetapkan indikator runtuk mengurangi angka kematian prematur dari Penyakit Tidak Menular (PTM) salah satunya Diabetes sebanyak sepertiga pada tahun 2030.

Motivasi diri pasien bergantung pada situasi kejiwaan yang sehat dan penyikapan terhadap permasalahan penyakit kronisnya. Pasien dengan Diabetes Mellitus cenderung akan mengalami distress berkaitan dengan masalah kesehatannya, serta penerimaan diri terhadap penyakit dan berbagai tindakan medis yang harus dilakukan sebagai prosedural perawatan yang harus dijalani oleh pasien. Penelitian ini bertujuan untuk mengetahui gambaran distress pada penderita Diabetes Mellitus.

\section{METODE}

Penelitian ini merupakan penelitian deskriptif kuantitatif. Sampel menggunakan accidental sampling dengan kriteria berada pada rentang usia $\geq 20$ tahun dan dapat berkomunikasi dengan baik dan tidak mengalami gangguan dalam berbicara. Diabetes Distress diukur menggunakan kuisioner. diabetic distress scale (DDS) 17 meliputi 4 domain, yaitu beban emosional, distres dengan dokter/tenaga kesehatan, distres pengobatan dan distres interpersonal. Analisis data dilakukan dengan deskriptif pada distribusi frekuensi masingmasing domain.

\section{HASIL}

Penelitian ini dilakukan pada 44 orang pasien DM tipe II yang di rawat di RS PKU Muhammadiyah Yogyakarta dan RS PKU Muhammadiyah Bantul.

1. Karakteristik Responden

Karakteristik responden dikategorikan berdasarkan jenis kelamin, usia, status menikah, pendidikan, pekerjaan, penghasilan, lama menderita dan asuransi. Deskripsi karakteristik responden dapat dilihat pada tabel 1 . 
Tabel 1.

Deskripsi Karakteristik Responden ( $\mathrm{n}=44)$

\begin{tabular}{lcc}
\hline Karakteristik & $\mathrm{f}$ & $\%$ \\
\hline Jenis Kelamin & & \\
Laki-laki & 17 & 38,6 \\
Perempuan & 27 & 61,4 \\
\hline Usia & & \\
$26-35$ tahun & 1 & 2,27 \\
$36-45$ tahun & 5 & 11,36 \\
$46-55$ tahun & 15 & 34,09 \\
$56-65$ tahun & 11 & 25,00 \\
$>$ 66 tahun & 12 & 27,27 \\
\hline Status Menikah & & \\
Kawin & 37 & 84,1 \\
Tidak Kawin & 2 & 4,5 \\
Cerai Mati & 5 & 11,4 \\
\hline Pendidikan & & \\
Tidak Sekolah & 1 & 2,3 \\
Pendidikan Dasar & 14 & 31,8 \\
Pendidikan Lanjut & 29 & 65,9 \\
\hline Pekerjaan & & \\
Bekerja & 21 & 47,7 \\
Tidak Bekerja: Ibu Rumah Tangga/Pensiun & 23 & 52,3 \\
\hline Penghasilan & & \\
<1 juta & 17 & 38,6 \\
1-3 juta & 21 & 47,7 \\
3juta & 6 & 13,6 \\
\hline 5 tahun & & \\
$>5$ tahun & 14 & 31,8 \\
\hline Riwayat DM dalam keluarga & 30 & 68,2 \\
Tda & & \\
\hline Kepemilikan Asuransi & 25 & 56,8 \\
Memiliki & 19 & 43,2 \\
Tidak Memiliki & 41 & 93,2 \\
Tabel & 3 & 6,8 \\
\hline
\end{tabular}

Tabel 1 menunjukkan responden sebagian responden telah menderita DM lebih dari 5 besar perempuan $(61,4 \%)$, rentang usia tahun $(68,2 \%)$ dan riwayat DM dalam terbesar 46-55 tahun $(34,09 \%)$ dan status keluarga terdapat pada hampir separuh menikah $84,1 \%$. Pendidikan sebagian besar responden $(56,8)$. Hampir seluruh tingkat lanjut (SMA dan perguruan tinggi) responden memiliki asuransi kesehatan $(65,9 \%)$. Responden yang bekerja lebih sedikit dibandingkan yang tidak bekerja (ibu rumah tangga dan pensiunan) dan rentang penghasilan sebagian besar 1-3 juta perbulan $(47,7 \%)$. Sebagian besar $(93,2 \%)$.

2. Diabetes Distress pada Penderita DM Tipe II Kategori diabetes distress penderita DM tipe II disajikan pada tabel 2.

Tabel 2.

Kategori Diabetes Distress pada Penderita DM Tipe II

\begin{tabular}{ccc}
\hline Kategori & $\mathrm{f}$ & $\%$ \\
\hline Rendah & 22 & 50,0 \\
Sedang & 20 & 45,5 \\
Tinggi & 2 & 4,5 \\
Total & 44 & 100 \\
\hline
\end{tabular}


Tabel 2 menunjukkan jumlah responden yang memiliki diabetes distress penderita DM tipe II dalam kategori rendah dan sedang hampir sama yaitu 22 orang $(50,0 \%)$ dan 20 orang $(45,5 \%)$.
Kategori diabetes distress penderita DM tipe II perdomain DDS disajikan pada tabel 3. Distribusi Frekwensi diabetes distress penderita DM tipe 2 disajikan pada tabel 4.

Tabel 3.

Kategori Diabetes Distress pada Penderita DM Tipe II Per Domain $(n=44)$

\begin{tabular}{lccc}
\hline \multicolumn{1}{c}{ Diabetes Distress } & Kategori & $\mathrm{f}$ & $\%$ \\
\hline Distres Beban Emosional & Rendah & 12 & 27,3 \\
& Sedang & 21 & 47,7 \\
& Tinggi & 11 & 25,0 \\
\hline Distres dengan dokter/ Tenaga Kesehatan & Rendah & 20 & 45,5 \\
& Sedang & 19 & 43,2 \\
& Tinggi & 5 & 11,4 \\
\hline Distres Pengobatan & Rendah & 19 & 43,2 \\
& Sedang & 19 & 43,2 \\
& Tinggi & 6 & 13,6 \\
\hline Distres Interpersonal & Rendah & 21 & 47,7 \\
& Sedang & 20 & 45,5 \\
& Tinggi & 3 & 6,8 \\
\hline
\end{tabular}

Tabel 4.

Distribusi Frekwensi Diabetic Distress Pasien DM Tipe II

\begin{tabular}{cccr}
\hline Variabel & Rerata & Minimum & Maksimum \\
\hline Diabetic Distress Penderita DM Tipe II & 2,08 & 1 & 4,9 \\
\hline
\end{tabular}

Tabel 5.

Distribusi Frekwensi Domain Diabetes Distress Penderita DM Tipe II

\begin{tabular}{llccc}
\hline \multicolumn{2}{c}{ Domain DDS } & Rerata & Minimum & Maksimum \\
\hline Distres Beban Emosional & & 2,28 & 1 & 5 \\
\hline $\begin{array}{l}\text { Distres dengan dokter/ } \\
\text { Kesehatan }\end{array}$ & Tenaga & 2,09 & 1 & 4,75
\end{tabular}

\begin{tabular}{lllc}
\hline Distres Pengobatan & 2,14 & 1 & 5 \\
\hline Distres Interpersonal & 1,90 & 1 & 4,67
\end{tabular}

Tabel 5 menunjukkan nilai rerata tertinggi lingkungan (Chew, Mohd-Sidik \& Shariffdiabetes distress penderita DM tipe II terdapat pada distres beban emosioanl yaitu 2,28 dan nilai maksimum tertinggi diabetes distress penderita DM tipe II terdapat pada distres beban emosioanal dan distress interpersonal yaitu 5.

\section{PEMBAHASAN}

Diabetes Distress menggambarkan beban emosional yang disebabkan oleh tekanan dalam perawatan mandiri diabetes serta komplikasi yang menyertainya (Polonsky et al., 2005; Snoek, Bremmer \& Hermanns, 2015). Beban emosional tersebut akan berdampak pada pasien itu sendiri, keluarganya dan pemberi pelayanan kesehatan yang terlibat dalam perawatan diabetes. Diabetes distress mengakibatkan menurunnya kualitas hidup yang berhubungan dengan kesehatan pada seluruh domain yaitu fisik, psikologis, hubungan sosial dan
Ghazali, 2015).

Distress pada penderita diabetes dipengaruhi oleh kognitif, lama sakit, kepribadian dan faktor ekonomi (Siregar\&Hidajat, 2017). Wardian, 2014 cit. Permana, 2017 menyebutkan faktor yang berhubungan dengan diabetes distress adalah usia, indeks masa tubuh, pelayanan kesehatan profesional dan efikasi diri. Rendahnya tingkat distress pada hasil penelitian dianalisis berdasarkan beberapara karakteristik responden yang menunjukkan kondisi positif yaitu usia, status menikah, pendidikan, pekerjaan dan kepemilikian jaminan kesehatan. Responden penelitian ini menunjukkan karakteristik yang mendukung pada rendahnya tingkat stress. Hasil penelitian menunjukkan sebagian besar tingkat pendidikan responden berada di tingkat lanjut yaitu SMA dan perguruan tinggi sebesar $65,9 \%$. 
Tingkat pendidikan seseorang berhubungan dengan pengetahuan seseorang. Tingkat pendidikan dapat meningkatkan pengetahuan tentang kesehatan. Pendidikan merupakan hal yang sangat penting dalam mempengaruhi pikiran seseorang. Seorang yang berpendidikan ketika menemui suatu masalah akan berusaha berfikir sebaik mungkin dalam menyelesaikan masalah tersebut. Orang yang berpendidikan baik cenderung akan mampu berfikir tenang terhadap suatu masalah. Penelitian Siregar (2017) menyebutkan faktor kognitif mempengaruhi cara berfikir patisipan dalam menemukan solusi yang tepat dari masalah yang dihadapi. Koping merupakan usaha seseorang untuk mengurangi stres yang merupakan proses pengaturan (management) beban yang dihadapi. Koping mengarahkan individu untuk mendefinisikan masalah, mencari alternatif pemecahan, mengukur alternative dari segi keuntungan dan kerugian, menentukan pilihan dan melaksanakan tindakan (Lazarus\&Folkman, 1986 cit Sadikin, 2013). Tingkat pendidikan berkaitan dengan kemudahan dalam memahami informasi, penjelasan dan instruksi terkait dengan penyakit (Siregar, 2017). Kemampuan individu dalam beradaptasi dan menangani masalah akan mengurangi reaksi stress yang muncul akibat penyakit. Selain itu, kemampuan berespon dan kematangan berfikir juga berkaitan dengan tingkat usia (Sadikin\&Subekti, 2013). Sehingga rendahnya tingkat diabetes distress pada penelitian ini diperkuat dengan usia responden yang sebagian besar berada pada rentang 46-55 tahun $(34,09 \%)$.

Karakteristik responden penelitian ini menurut jenis kelamin menunjukkan sebagian besar responden adalah perempuan perempuan $(61,4 \%)$ dengan rentang usia terbesar 46-55 tahun $(34,09 \%)$. Prevalensi DM pada perempuan dibuktikan dalam penelitian Jelantik (2014 cit Permana, 2017) yaitu terdapat hubungan faktor risiko umur, jenis kelamin, kegemukan dan hipertensi dengan kejadian DM tipe 2 di wilayah Kerja Puskesmas Mataram Tahun 2013, dimana sebagian besar berjenis kelamin perempuan. Peningkatan umur menyebabkan seseorang beresiko terhadap peningkatan kejadian DM, orang yang memasuki 6 usia 55 tahun keatas, berkaitan dengan terjadinya diabetes karena pada usia tua, fungsi tubuh secara fisiologis menurun karena terjadi penurunan sekresi atau resistensi insulin sehingga kemampuan fungsi tubuh terhadap pengendalian glukosa darah yang tinggi kurang optimal (Suyono, 2007 cit Permana, 2017). Kekenusa (2013 cit Permana, 2017) menyimpulkan bahwa terdapat hubungan antara umur dan riwayat hidup dengan kejadian DM tipe 2 , dimana orang yang berumur lebih dari 45 tahun memiliki resiko menderita DM tipe 2 delapan kali lebih tinggi dibandingkan orang yang berusia dibawah 45 tahun.

Sebagian besar responden telah menderita DM lebih dari 5 tahun $(68,2 \%)$. Lama sakit berkaitan dengan proses adaptasi terhadap masalah yang dihadapi. Hal ini sejalan dengan hasil penelitian Permana (2017) yang menyebutkan bahwa distribusi frekuensi lama sakit responden penderita DM menunjukkan distribusi tertinggi pada lebih dari 10 tahun dan tingkat distress pasien sebagian besar adalah ringan. Permana (2017) menyatakan terdapat hubungan antara lama sakit dengan tingkat distress pada pasien diabetes mellitus di Rumah Sakit Islam Surakarta $(\mathrm{p}$-value $=0,001)$ dimana semakin lama sakit, maka tingkat distress semakin rendah. Semakin rendah tingkat stress dalm kondisi sakit yang semakin lama menunjukkan pasien semakin memahami kondisi yang dirasakan baik dari segi fisik, psikologis, hubungan sosial dan lingkungan. Pemahaman yang dialami pasien terhadap sakitnya akan mendorong pasien untuk lebih mampu mengantisipasi munculnya kegawatan atau sesuatu hal yang mungkin terjadi pada diri pasien (Permana, 2017).

Hampir seluruh responden dalam penelitian ini memiliki asuransi kesehatan $(93,2 \%)$. Hal ini merupakan faktor penting yang membantu menurunkan distress penderita. Diabetes Mellitus merupakan masalah kesehatan global yang paling serius, mengancam, berkembang pesat angka kejadian dan mengakibatkan morbiditas dan mortalitas serta meningkatkan biaya perawatan kesehatan terbanyak. Besarnya pembiayaan kesehatan akibat Diabetes tampak dari klaim BPJS sampai tahun 2015. Ternyata Diabetes dan komplikasinya adalah salah satu kelompok klaim terbesar untuk biaya catastrophic JKN, yaitu $33 \%$ dari total pengeluaran. Adanya jaminan kesehatan akan mengurangi beban pembiayaan yang harus ditanggung secara mandiri oleh penderita DM sehingga secara emosional seorang yang memiliki jaminan kesehatan menjadi lebih tenang dan yakin.

Status pernikahan sebagian besar responden penelitian ini adalah status menikah yaitu 84,1 
$\%$. Penderita diabetes membutuhkan kepatuhan dalam melakukan perawatan dan pengobatannya. Penderita DM membutuhkan bantuan, dukungan dan perhatian dari lingkungan disekitarnya untuk menjaga kepatuhan regimen yang dijalani. Dukungan keluarga merupakan suatu pertolongan dari keluarga untuk memberikan kenyamanan fisik dan psikologis pada keadaan stres. Dukungan emosional dari orang terdekat menimbulkan ketenangan, kenyamanan dan meminimalkan reaksi negativ kecemasan (Wardani, 2017). Penelitian Wardani (2017) menyebutkan terdapat hubungan antara dukungan keluarga dengan perilaku distres pada pasien diabetes di RSUD Dr. Moewardi. Koefisien korelasi bernilai negatif yang menunjukkan bahwa dukungan keluarga dan perilaku distres berlawanan arah, sehingga dukungan keluarga yang tinggi mengakibatkan rendahnya perilaku distres. Sebaliknya, rendahnya dukungan keluarga mengakibatkan semakin tinggi perilaku distress. Hal ini tidak sesuai dengan penetian Yumna (2018) tidak ada hubungan antara dukungan keluarga dengan distress pasien diabetes dengan nilai $p$ value 0,155 .

Diabetes distress memiliki 4 domain yaitu distress beban emosional, distress dengan dokter/tenaga kesehatan, distress pengobatan, distress interpersonal. Hasil penelitian pada 4 domain diabetes distress menunjukkan urutan berdasarkan rerata tertinggi yaitu distress beban emosional $(2,28)$, distress pengobatan $(2,14)$, distress dengan dokter/tenaga kesehatan $(2,09)$ dan distress interpersonal $(1,90)$. Hal ini sejalan dengan hasil penelitian Permana (2017) bahwa komponen distress yang paling dominan terhadap timbulnya distres pasien adalah beban emosional.

\section{SIMPULAN DAN SARAN}

\section{Simpulan}

1. Sebagian responden mengalami diabetes distress tingkat rendah (50\%), 45,5\% responden mengalami diabetes distress tingkat sedang dan hanya sedikit $(4,5 \%)$ responden yang mengalami diabetes distress tingkat tinggi.

2. Domain diabetes distress yang paling tinggi adalah distress beban emosional $(2,28)$, selanjutnya distress pengobatan $(2,14)$, distress dengan dokter/tenaga kesehatan $(2,09)$ dan nilai terendah terdapat pada distress interpersonal $(1,90)$.

\section{Saran}

1. Perlu dipertahankan faktor-faktor yang berkontribusi positif dalam menurunkan tingkat distress penderita DM tipe II yang dapat dimodifikasi diantaranya pengetahuan dan dukungan keluarga.

2. Perlu diberikan edukasi atau pelatihan yang dapat menguatkan respon emosional penderita DM tipe II misalnya konseling, terapi psikologis, keterampilan komunikasi dan peningkatan koping.

\section{DAFTAR PUSTAKA}

Arifin, B, Dyah Aryani Perwitasari, Thobari, JA, Cao, Q, Krabbe, PFM \& Postma, MJ 2017,' Translation, Revision, and Validation of the Diabetes Distress Scale for Indonesian Type 2 Diabetic Outpatients with Various Types of Complications', Value in Health Regional Issues, 12C:63-73

Chew, BH, Mohd-Sidik, S \& Shariff-Ghazali, S 2015, 'Negative effects of diabetesrelateddistress on health-related quality of life: an evaluation among the adult patients with type 2 diabetes mellitus in three primary healthcare clinics in Malaysia', Health and Quality of Life Outcomes, 13:187

Chew, BH, Vos, R, Mohd-Sidik, S, Rutten, GEHM 2016, 'Diabetes-Related Distress, Depression and DistressDepression among Adults with Type 2 Diabetes Mellitus in Malaysia, PLoS ONE 11(3): e0152095.

Fisher L, Mullan JT, Arean P, Glasgow RE, Hessler D, Masharani U. 2010, 'Diabetes distress but not clinical depression or depressive symptoms is associated with glycemic control in both crosssectional and longitudinal analyses. Diabetes Care; 33: 23-28.

Permana, Y. I. (2017). Hubungan antara lama sakit dengan tingkat distress pada pasien dengan Diabetes mellitus di Rumah Sakit Islam Surakarta. Skripsi. http://eprints.ums.ac.id/52058/2/NASK AH\%20PUBLIKASI.pdf. Diakses tanggal 26 September 2018.

Polonsky, WH, Fisher, L, Earles, J, Dudl, RJ, Lees, J, Mullan, J \& Jackson, RA 2005,' Assessing Psychosocial Distress 
in Diabetes: Development of the Diabetes Distress Scale', Diabetes Care 28:626-631

Sadikin,, LM. Subekti, EM. 2013. Coping Stres pada penderita Diabetes Mellitus Pasca Amputasi. Jurnal Psikologi Klinis dan Kesehatan Mental. Vol 02 No 03.

Strandberg, R.B, Graue1, M, Wentzel-Larsen, T, Peyrot, M, Thordarson, H.B., \& Rokne, B 2015,' Research: Educational and Psychological Issues Longitudinal relationship between diabetes-specific emotional distress and follow-up HbAlc in adults with Type 1 diabetes mellitus', Diabetic Medicine. 32, 13041310 .

Siregar, LB \&Hidajat, LL. 2017. Faktor yang Berperan Terhadap Deprsesi,
Kecemasan dan Stres pada Penderita Diabetes Melitus Tipe 2: Studi Kasus Puskesams Kecamatan Gambir Jakarta Pusat. Jurnal Ilmiah Psikologi MANASA. Vol 6, No. 1

Wardani, D. K. (2017). Hubungan Dukungan Keluarga dengan Perilaku distress pada pasien dengan Diabetes mellitus di Rumah Sakit Moewardi. Skripsi. http://eprints.ums.ac.id/53777/14/NAS KAH\%20PUBLIKASI.pdf.Diakses tanggal 26 September 2018.

Yumna, M, Diani N, Setyowati, A. 2018. Dukungan Keluarga dengan Distress pada pasien Diabetes Melitus. 